\title{
A new deep-sea isopod from the Weddell Sea, Antarctica: Coperonus pinguis n. sp. (Crustacea, Isopoda, Munnopsidae)
}

\author{
Angelika Brandt \\ Institut für Polarökologie, Universität Kiel, Olshausenstr. 40-60, 2300 Kiel, Germany
}

Keywords: taxonomy, biogeography, Antarctica, Weddell Sea, deep sea, Coperonus

\begin{abstract}
A new species of Coperonus, $C$. pinguis, is described from the Antarctic deep sea. It is the first record of an Antarctic deep-sea species in this genus and the southernmost record of Coperonus.
\end{abstract}

\section{Zusammenfassung}

Eine neue Art der Gattung Coperonus, $C$. pinguis, wird aus der antarktischen Tiefsee beschrieben. Dies ist der erste Fund einer antarktischen Tiefseeart dieser Gattung; außerdem stellt er den bisher südlichsten Fund der Coperonus-Arten dar.

\section{Introduction}

A Coperonus species hitherto unknown to science was discovered among isopods collected during the European Polarstern Expedition in the Antarctic summer of $1988 / 89$. The natatory munnopsid isopod crustaceans of the genus Coperonus are distributed in the Argentine Basin, around South Georgia and the South Shetland Islands, in the Weddell Sea, and at the Gauss Station in eastern Antarctica (Fig. 1). Up to the present the occurrence of Coperonus has been restricted to the southern hemisphere; the genus has not been found north of Brazil. All Antarctic species have been sampled off the continental shelf.

The first description of a member of Coperonus Wilson, 1989 was presented by Vanhöffen (1914), then still included in the genus Eurycope (cf.
Brandt, in press). Since then, no Coperonus species has been found south of $72^{\circ} \mathrm{S}$. Only one species is known from the deep sea, $C$. comptus Wilson, 1989 , although the genus undoubtedly is of deepsea origin, as generally accepted for the munnopsid genera (Hessler \& Thistle, 1975; Hessler \& Wilson, 1983; Wägele, 1989; Wilson, 1987, 1989).

\section{Material and methods}

The single specimen was collected during the "European Polarstern Expedition" in the Antarctic summer 1988/89 in the southern Weddell Sea by means of an Agassiz trawl. On deck, subsamples were taken and later pre-sorted in the "Centre National de Tri D'Océanographie Biologique" (CENTOB, IFREMER, Brest). In the laboratory the material was sorted under a Wild M5 dissecting microscope and illustrated using a Leitz Dialux microscope, equipped with a camera lucida. The terminology of the chaetotaxy is used as proposed by Hessler (1970).

The following abbreviations are used in text and figures: A1 = antennula; A2 = antenna; EPOS = European "Polarstern" Study; $\mathrm{H}=$ head; $\mathrm{Hy}=$ Hypopharynx; lMd = left mandible; $M x 1=$ maxillula; $\mathrm{Mx} 2=$ maxilla; $\mathrm{Mxp}=$ maxilliped; $\mathrm{PI}-7=$ pereopods $1-7$; Plp $1-5=$ pleopods $1-5 ; \mathrm{rMd}=$ right mandible; Urp = uropod; ZMB = Zoological Museum, Berlin. 


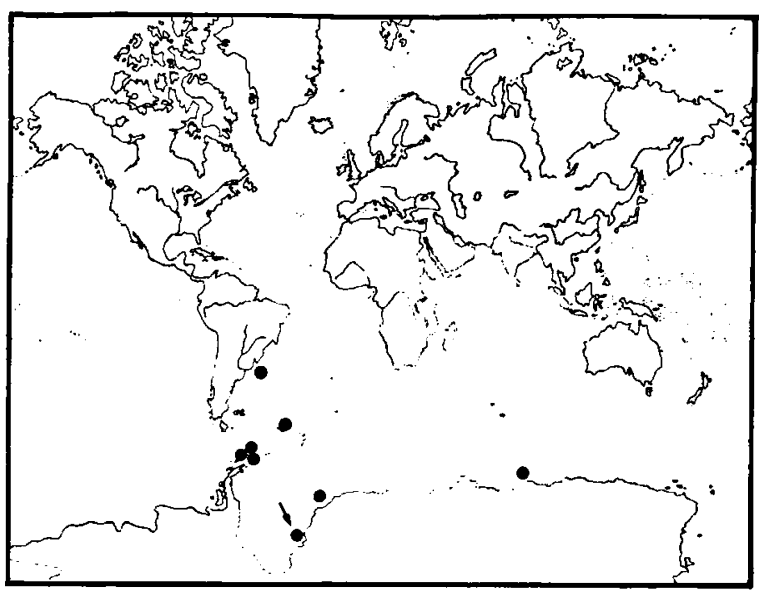

Fig. 1. Distribution of the genus Coperonus. The type locality of $C$. pinguis $\mathrm{n}$. sp. is indicated by the arrow.

\section{Results}

Coperonus pinguis n. sp.

(Figs. 2-4)

Holotype. - Mature male of $5.5 \mathrm{~mm}$ length, ZMB Nr. 26925 (slides 4161-4165).

Type locality. - "EPOS" Sta. $253,74^{\circ} 09.5^{\prime} \mathrm{S} 29^{\circ} 41.4^{\prime} \mathrm{W}-74^{\circ}$ 08'S 3003.3' W, 2012-1996 m depth, Agassiz trawl (7 Feb. 1989).

Distribution. - Southern Weddell Sea, only known from the type locality.

Derivation of name. - Pinguis means "fat" or "large" in Latin. C. pinguis is the largest of the hitherto known species of Coperonus.

Diagnosis. - Dorsum smooth, lateral margins of natasome and pleotelson with short simple setae. Natasome very long (about 2.8 times as long as head and anterior pereonites). Pleotelson with small mediodorsal elevation (visible in lateral view); medial surface shallowly indented and caudal apex of pleotelson with elevated rounded tip (see Fig. 2 lateral view). Antennulae very long and strong, first article very broad ( 0.4 of cephalon width), with 2 medial broom setae. Second peduncular article with distolateral protrusion, third article very much prolonged (about three times as long as second article), with 12 small sensory setae and a broom seta.
Fourth article slightly shorter than article 2, with 3 long and 5 short sensory setae. Maxilliped covered with small scales; medial margin of palp articles 3-5 with many plumose setae. Basis of pereopod 6 with long simple ventral setae and long dorsal plumose setae. Propodus of pereopod 7 lacking ventral plumose setae. Uropod with exopodite about half as long as endopodite.

Description of the male holotype. - Length 5.5 $\mathrm{mm}$, length 2.3 times width. Body depth about 0.3 times length. Pleotelson width $0.7-0.8$ times natasome width and pleotelson length $0.8-0.9$ times width.

Body setation: dorsum of body lacking long setae (Fig. 2), but with short simple setae on natasome and pleotelson.

Clypeus as high as flattened frons, deep gap between frons and clypeus.

Pereonite 1 medially shortest and narrowest (Fig. 2). Pereonites $2-4$ subequal in length, broadening anteriorly, pereonite 4 partly covered by natasome. Lateral margins of pereonite 7 completely covered by pleotelson.

Antennula (Fig. 2): tip of flagellum broken off (17 flagellar articles and 5 aesthetascs present), interantennula gap 0.4 times cephalon width. First article: medial length about as long as width. Medial lobe with 2 broom setae of different lengths and 1 simple short seta. Lateral margin with 5 small sensory setae. Second article smaller than first, with distolateral broom seta and 1 simple seta. Third article.longest. Article 4 about as long as article 2, article 5 shorter than article 4 (0.7 times length of article 4). Following flagellar articles bent ventrally under the anterior part of the body.

Antenna (Fig. 3) broken off, only proximal articles illustrated, all with varying number of sensory setae; third article with 4 apical and a row of 5 lateral sensory setae.

Mandible (Figs. 2 and 3): left mandible with 3 distinct cusps on incisor process; right mandible only with 2 cusps, not very distinct. Lacinia mobilis shorter than incisor, with 3 cusps. Both spine rows with 8 spines. Both molar posterior margins with 3 flattened setulated setae. Condyle length 0.26 times mandibular body length. Palp article 2 with 4 short 


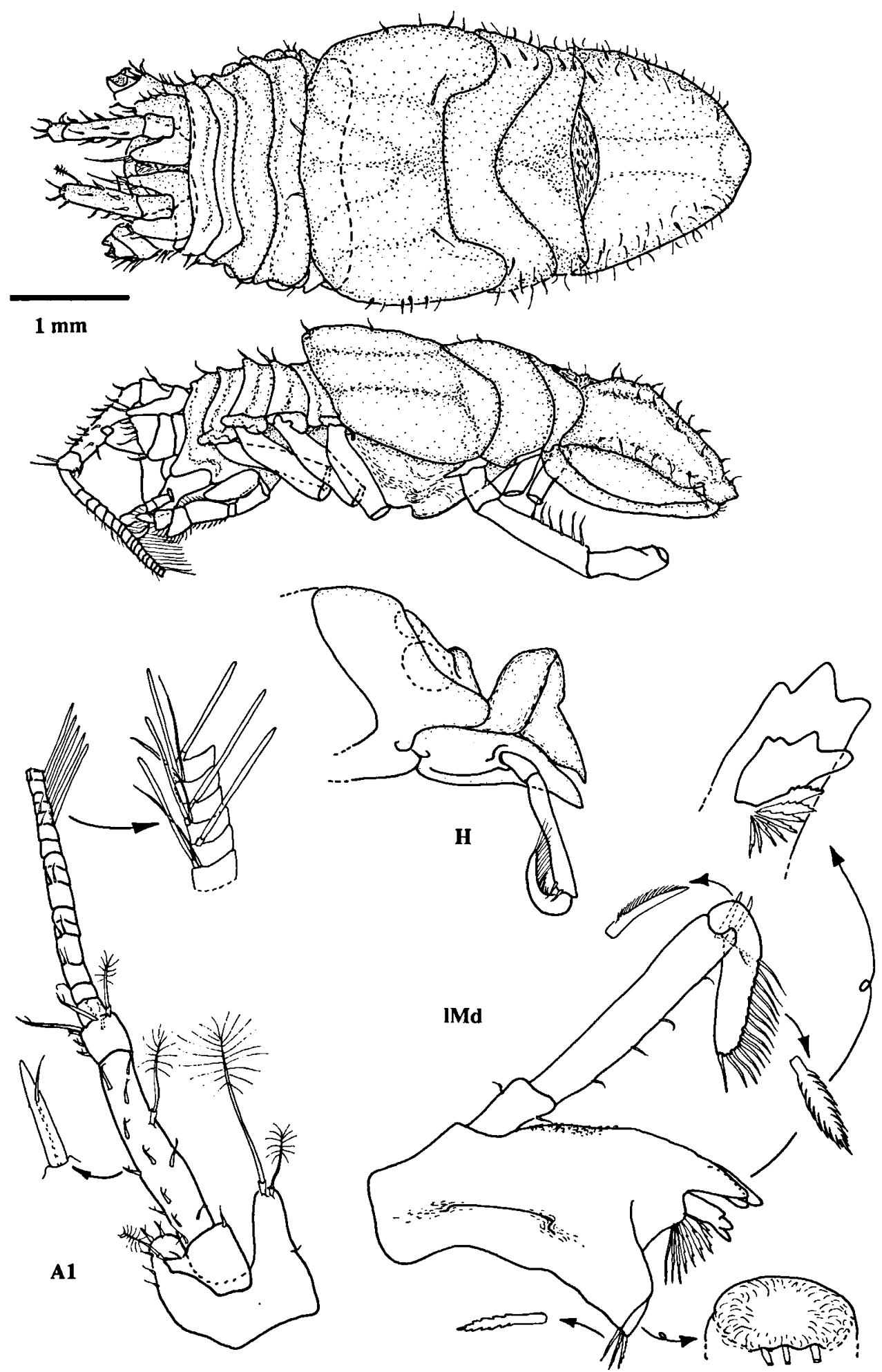

Fig. 2. Holotype male of Coperonus pinguis n. sp. in dorsal and lateral view, head in lateral view, antennula, and left mandible. 


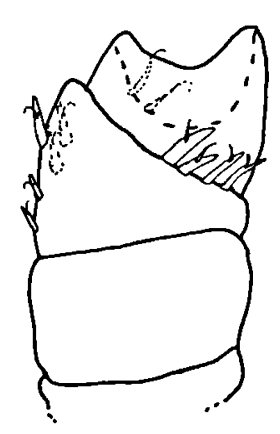

A2
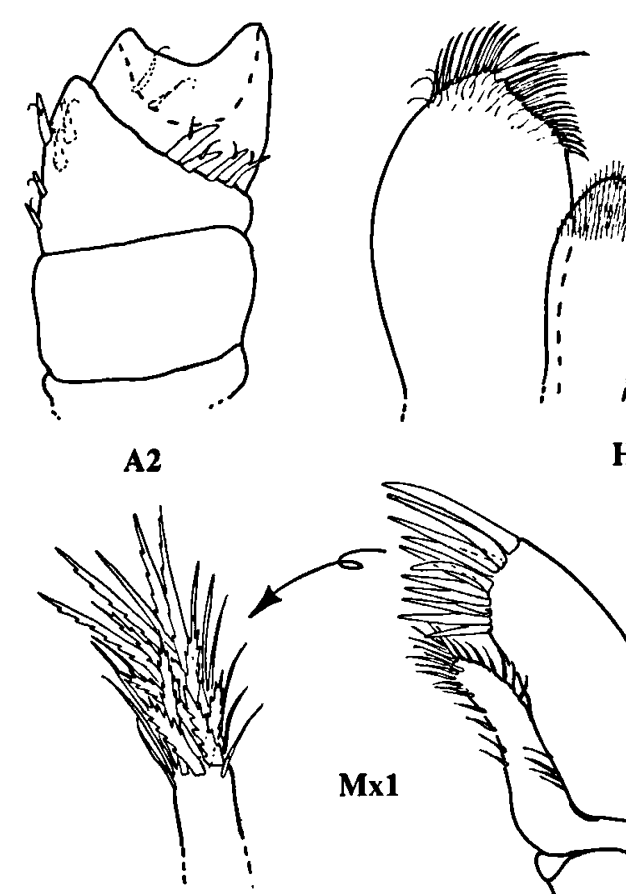

Hy
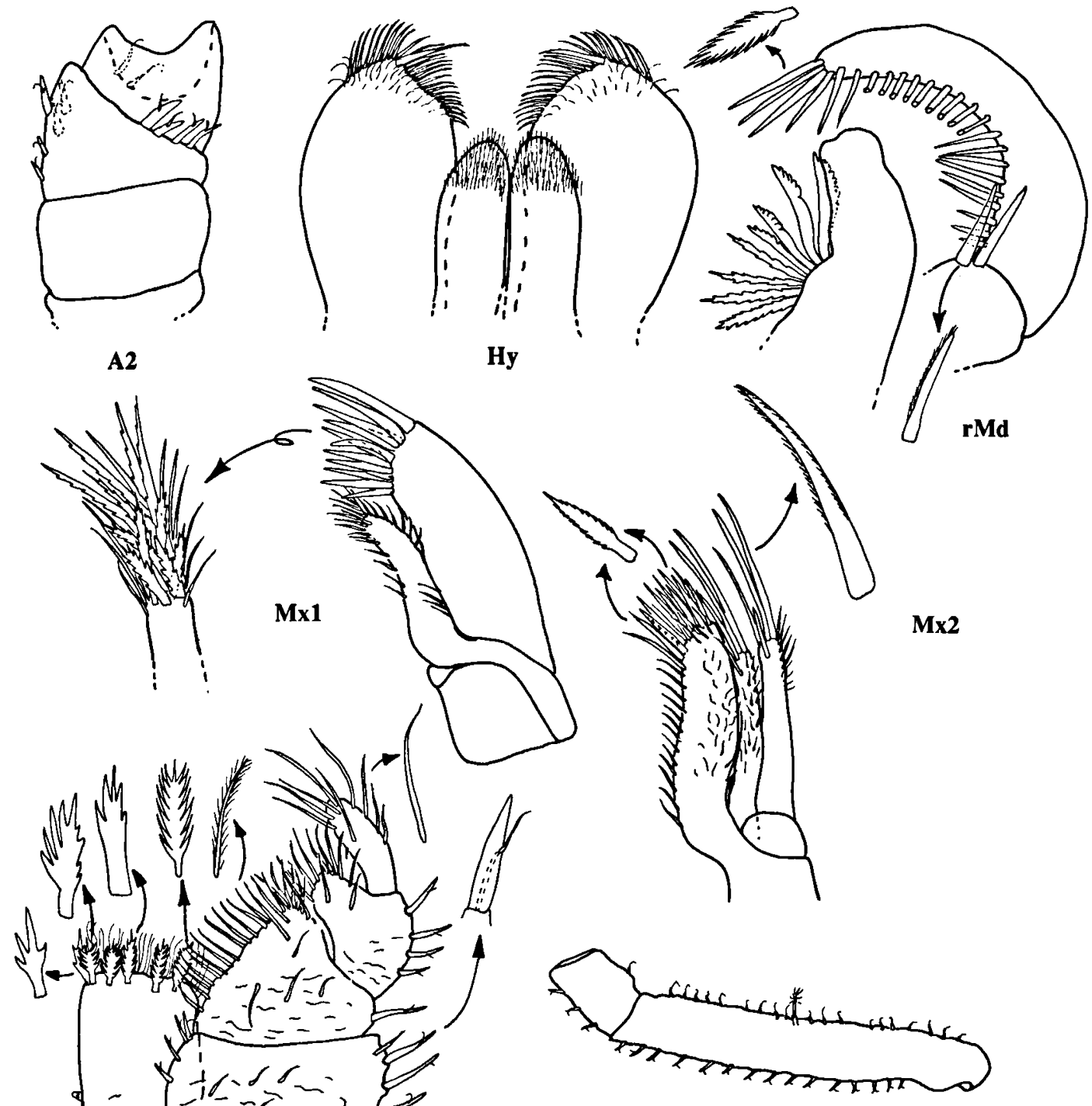

P1
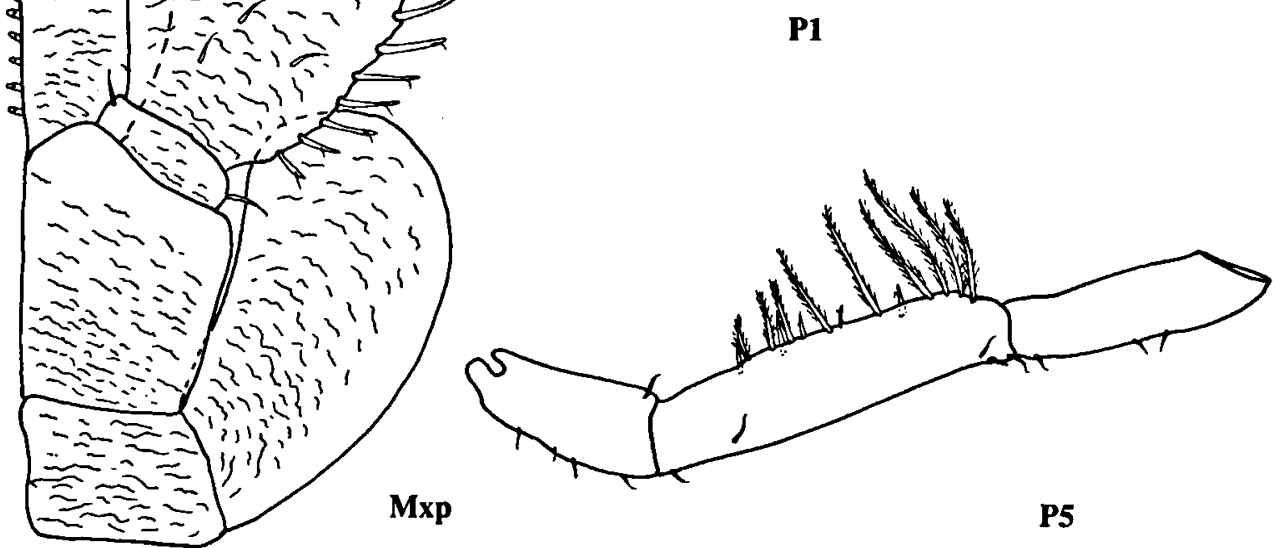

P5

Fig. 3. Holotype male of Coperonus pinguis n. sp.: antenna, hypopharynx, pars incisiva and third palp article of right mandible, maxillula, maxilla, maxilliped, basis of pereopod 1 , and basis to merus of pereopod 5 . 
simple setae and 2 distal heavily setulated setae.

Hypopharynx (Fig. 3) consisting of two voluminous lobes and two shorter and smaller lobes with many distal setae.

Maxillula (Fig. 3): inner endite width 0.57 times outer endite width. Outer endite with 11 strong spine-like setae, some of which serrated.

Maxilla (Fig. 3): inner endite largest, with many distal setae, some of which setulated; medial endite with 3, outer endite with 4 long serrated setae.

Maxilliped (Fig. 3): coxa quadrangular, lacking setae. Basis with 6 receptacula and 6 fan setae distally. Second palp article laterally with a row of strong sensory setae and 4 shorter distomedial sensory setae. Articles 2 and 3 with 6 and 4 short simple ventral setae. Epipodite length 2.1 times width and 0.8 times total basis length.

Pereopodal bases (Figs. 3 and 4): length of basis of P1 0.24 times body length. Bases of P2-P4 broken off in this specimen; bases of P5-P7 length to body length ratio $0.10,0.14$, and 0.15 times of body length, respectively.

Pereopod 1 (Fig. 3) broken off in this specimen at ischium; basis with a row of 15 ventral small sensory setae, a row of 19 dorsal whip setae, and a small dorsal broom seta.

Pereopods 2-4 broken off in this specimen.

Natatory pereopods (Fig. 4): pereopods 5-7 length to body length ratios $0.8,0.6$, and 0.5 .

Basis of pereopod 5 short, length 0.1 of body length, with 4 short ventral setae and 1 dorsal simple seta. Ischium about twice as long as basis, with 9 dorsal plumose setae of varying lengths, accompanied by a row of 5 small sensory setae. Merus length 0.7 of ischium length, with 3 ventral simple short setae. Following articles broken off in this specimen.

Pereopod 6 (Fig. 4): basis with 10 ventral simple and 2 distoventral whip setae, and a dorsal row of 9 long plumose setae. Ischium half as long as basis, with 8 ventral short whip and 8 dorsal long plumose setae, merus about as long as ischium, with 9 ventral whip setae. Carpus and propodus dorsally and ventrally with rows of long plumose setae, dactylus long and slender, half as long as propodus.

Pereopod 7 (Fig. 4): basis with 9 long ventral plumose setae; ischium length 0.3 of basis length, with 2 proximoventral plumose setae and 7 ventral whip setae and 2 ventral plumose setae; merus about as long as ischium, with a single distoventral simple seta. Carpus with rows of long plumose setae dorsally and ventrally. Propodus as long as carpus, only with a dorsal row of long plumose setae, propodus width 0.5 of that of P6. Dactylus as in $\mathrm{P} 6,0.5$ of propodus length.

Pleopod 1 (Fig. 4) narrowing after about one third of its length. Four times as long as proximal width, distal width 0.4 of proximal width. Tips flat in ventral view. Fine setae on distal half of ventral surface.

Pleopod 2 (Fig. 4): sympodite length 1.8 of its width. Lateral margin of sympodite slightly rounded with a row of many short plumose setae, 4 distolateral short whip setae and small distal setules. Endopodite inserting at 0.3 of sympodite length from distal tip. Stylet with acute tip, length approximately 0.4 of sympodite length, not reaching to distal tip of the article; sperm duct half as long as stylet. Exopodite small, with few fine setae.

Pleopod 3 (Fig. 4): exopodite with 2 long plumose setae and a medial shorter simple seta. Endopodite with 3 plumose setae.

Pleopod 4 (Fig. 4): exopodite with a long plumose seta. Endopodite without setation.

Pleopod 5 (Fig. 4): simple, smooth, without any setation.

Uropod (Fig. 4): medial length of sympodite about 0.8 of its distal width. Distal margin of sympodite with 2 long whip setae on medial and 1 long whip seta on lateral lobe. Exopodite about 0.5 of endopodite length, with 1 distal whip seta. Endopodite length 0.9 of medial length of sympodite, with 7 broom setae and 1 simple seta.

\section{Discussion}

The "EPOS" material contained only a single specimen of Coperonus pinguis $\mathrm{n}$. sp. It is the largest known species of the genus and it can easily be distinguished from the other species of Coperonus by very characteristic apomorphic characters, viz.: (1) the long and strong male antennulae; (2) the long setae on the basis of pereopod 6, and (3) the 


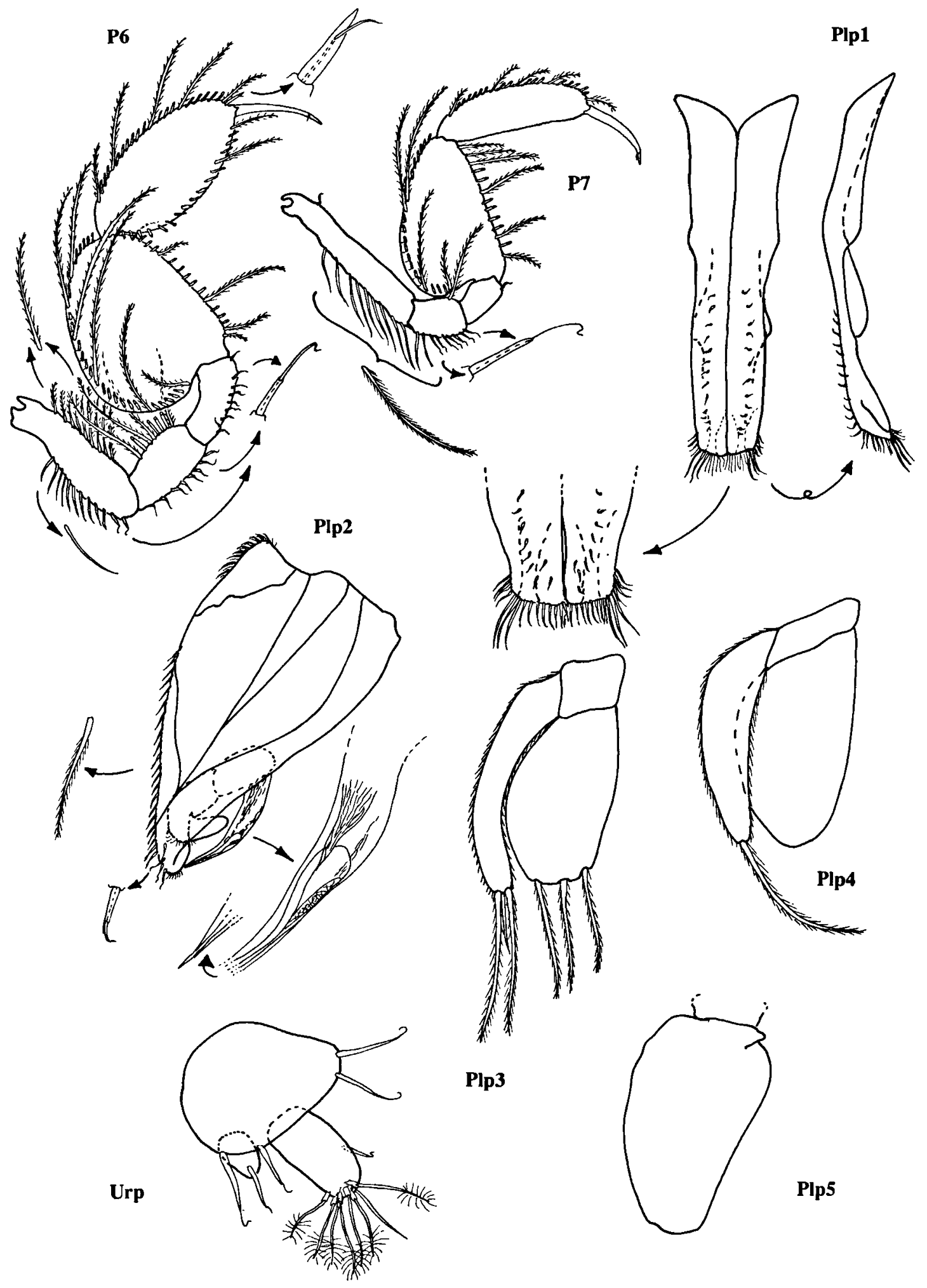

Fig. 4. Holotype male of Coperonus pinguis n. sp.: pereopods 6 and 7, pleopods 1-5, and uropod. 
ventral side of the propodus of pereopod 7 without plumose setae.

C. pinguis is also characterized by small simple setae on the lateral margins of the natasome and pleotelson. These are also present in C. comptus Wilson, 1989, but in the latter they are more numerous and very fine. Besides, the third antennular article is very much prolonged in $C$. pinguis, in contrast to the other species of the genus. Moreover, pereopod 6 of $C$. pinguis bears a row of short sensory setae on the dorsal side of the ischium that accompanies the row of plumose setae. These short sensory setae are absent in the other Coperonus species.

Until now the centre of distribution of Coperonus is the Atlantic sector of the Southern Ocean (Fig. 1). Only a single species, $C$. comptus, has been found in the deep Argentine Basin and $C$. frigida (Vanhöffen, 1914) has been found in the Indian sector of the Antarctic Ocean at the Gauss Station.

Vertically the species of Coperonus range from 139-2707 m depth. Until now, most of the species have been found on the continental shelf. Besides this new deep-sea species, only $C$. comptus Wilson, 1989 has been found in the deep Argentine Basin in the southwestern Atlantic Ocean between 497 and $2707 \mathrm{~m}$.

\section{Acknowledgements}

For logistics the author is grateful to the Alfred Wegener Institute of Polar Research. The isopod material was collected during the European “Polarstern" Study (EPOS) sponsored by the European Science Foundation and the Alfred Wegener Institute for Polar Research. The material was pre-sorted by the Centre National de Tri d'Océanographie Biologique (CENTOB, IFREMER, Brest).

\section{References}

Brandt, A., in press. Revision of the genus Coperonus (Isopoda: Munnopsidae: Lipomerinae). Zool. J. Linn. Soc.

Hessler, R.R., 1970. The Desmosomatidae (Isopoda, Asellota) of the Gay Head - Bermuda Transect. Bull. Scripps Inst. Oceanogr. Univ. Calif., San Diego, 15: 1-185.

Hessler, R.R. \& D. Thistle, 1975. On the place of origin of deepsea isopods. Mar. Biol., 32: 155-165.

Hessler, R.R. \& G.D.F. Wilson, 1983. The origin and biogeography of malacostracan crustaceans in the deep sea. In: $R$.W. Sims, J.H. Price \& P.E.S. Whalley (eds.), Evolution, time and space: the emergence of the biosphere. Systematics Association Special Volume, 23: 227-254 (Academic Press, London).

Vanhöffen, E., 1914. Die Isopoden der Deutschen SüdpolarExpedition 1901-1903. Deutsche Südpolar Expedition, 15 (Zool.) 7: 447-598.

Wägele, J.W., 1989. Evolution und phylogenetisches System der Isopoda. Stand der Forschung und neue Erkenntnisse. Zoologica (Stuttgart), 140: 1-262 [E. Schweitzerbart'sche Verlagsbuchhandlung (Nägele \& Obermiller), Stuttgart].

Wilson, G.D.F., 1987. The road to the Janiroidea: Comparative morphology and evolution of asellote isopod crustaceans. $Z$. zool. Syst. Evolut.-forsch., 25: 257-280.

Wilson, G.D.F., 1989. A systematic revision of the deep-sea subfamily Lipomerinae of the isopod crustacean family Munnopsidae. Bull. Scripps Inst. Oceanogr. Univ. Calif., San Diego, 27: 1-138.

Received: 31 May 1991 